\title{
New Approaches to Reaction Kinetics during Molten Aluminium Refining Using Electron Backscatter Diffraction (EBSD)
}

\author{
Alfredo Flores and Jesús Torres \\ Centro de Investigación y de Estudios Avanzados del IPN, Unidad Saltillo \\ México
}

\section{Introduction}

The use of aluminium scrap to produce different alloys has increased considerably at the start of the current century because of the low amount of energy required for its melting, in comparison to the energy required to produce aluminium from bauxite. However, contamination problems can arise if the different kinds of scrap with several chemical compositions are not separated using appropriate methods. In this way, contamination with elements such as $\mathrm{Fe}, \mathrm{Sb}, \mathrm{Mg}$, $\mathrm{Na}, \mathrm{K}, \mathrm{Pb}$, and $\mathrm{Sn}$ is quite common, so melt treatment practices have been recommended. Of these contaminants, antimony is considered to be among the most harmful because of its high potential toxicity, which is of special concern for products intended for handling of food and drink. Also, modification with sodium and/or strontium is not effective because of the formation of intermetallic compounds that remove these elements from solution, preventing any effect of this modification on the eutectic silicon phase.

The negative effects of antimony on the rate of modification of the silicon eutectic with sodium and/or strontium in casting Al-Si alloys have been broadly studied by (Wang \& Gruzleski, 1990), (Wang \& Gruzleski, 1992), (Garant et al., 1992), and (Tuttle et al., 1991). The general problem in mixing antimony with sodium and/or strontium is the formation of high melting temperature compounds that are difficult to remove. Moreover, it is possible to generate phases with harmful morphologies that affect the mechanical properties of this type of alloy. These compounds eliminate sodium and/or strontium from the solution, preventing the effect of sodium/strontium modification on the silicon eutectic phase. On the other hand, antimony has been shown to possess a great chemical affinity for calcium, forming stable compounds that can be removed through dross. However, to study the mechanism of reaction, it is first necessary to define the stoichiometry of the reaction. Different techniques have been proposed to hinder the effects of antimony, including dilution with pure aluminium, separation of polluted scrap, addition of an excess of the modifier agent, or removal by means of chemical agents, as described by (Castrejón, 1995). However, no effective method has yet been developed at the cast shop facility level. Antimony, among other elements, possesses great affinity for calcium, as demonstrated long ago by (Hardy, 1941), who established that $\mathrm{Ca}_{3} \mathrm{Sb}_{2}$ or AlSb phases could form when these elements are present in molten aluminium. Nevertheless, the mechanism of reaction outside of molten aluminium scrap has not been determined. 
Another important application of aluminium scrap from cans is the production of automotive alloys such as AA380, AA319 and AA356. However, these alloys specify no more than 0.10 wt.\% $\mathrm{Mg}$ to avoid the harmful effects of $\mathrm{Mg}$ on mechanical properties, as shown by (Caseres, 1999). Various techniques have been developed to remove $\mathrm{Mg}$ from molten aluminium, such as methods based on gaseous mixtures of $\mathrm{Ar} / \mathrm{Cl}_{2}$ or $\mathrm{Ar} / \mathrm{SF}_{6}$. Other techniques are based on the optimisation of solid reactive groups like $\mathrm{Na}_{2} \mathrm{SiF}_{6}, \mathrm{AlF}_{3}, \mathrm{KAlF}_{4}$ or $\mathrm{SiO}_{2}$. Previous studies performed by (Martinez, 19998) on the removal of $\mathrm{Mg}$ from Al-Si$\mathrm{Cu}$ alloys established that it is possible to remove $\mathrm{Mg}$ from $700{ }^{\circ} \mathrm{C}$ to $800{ }^{\circ} \mathrm{C}$ by injecting submerged $\mathrm{SiO}_{2}$ powder. This author claims that $\mathrm{Mg}$ removal takes place through the formation of a complex $\mathrm{MgAl}_{2} \mathrm{O}_{4}$ compound. On the other hand, (Escobedo et al., 2003) studied the removal of $\mathrm{Mg}$ from molten aluminium by injecting submerged powders of $\mathrm{SiO}_{2}$ particles with an irregular morphology, determining the reaction rate and the values of some kinetic parameters of technological interest. For some initial conditions, it was possible to remove almost $100 \%$ of the $\mathrm{Mg}$ in time periods on the order of $70 \mathrm{~min}$. The reaction was found to stop once the formation of a complex layer of reaction products covered the $\mathrm{SiO}_{2}$ particles. These authors suggested that the predominant reaction is transitory, indicating that contact time between the molten phase and the solid particles is quite rapid, occurring in fractions of a second. Therefore, the main disadvantage of this process is the entrapment of solid particles in the solidified alloy, called inclusions, as well as the excessive formation of slag rich in $\mathrm{MgAl}_{2} \mathrm{O}_{4}$ and agglomerates of $\mathrm{Al}_{2} \mathrm{O}_{3}-\mathrm{SiO}_{2}$ particles.

To better understand the reactions involved in the injection of submerged powders of $\mathrm{SiO}_{2}$ for $\mathrm{Mg}$ removal from molten aluminium, it is necessary to mention the elaboration of mullite refractories and metal-matrix composites. Al-Mg fibers surrounded by $\mathrm{Al}_{2} \mathrm{O}_{3} \mathrm{SiO}_{2}$ are taken as the products of the reaction of $\mathrm{MgO}$ and $\mathrm{MgAl}_{2} \mathrm{O}_{4}$. (Ghosh et al., 2003) studied the production of $\mathrm{MgAl}_{2} \mathrm{O}_{4}$ by direct reaction between $\mathrm{MgO}$ and $\mathrm{Al}_{2} \mathrm{O}_{3}$ at $1400{ }^{\circ} \mathrm{C}$, represented by the next equation:

$$
\begin{gathered}
\mathrm{MgO}(\mathrm{s})+\mathrm{Al}_{2} \mathrm{O}_{3}(\mathrm{~s})=\mathrm{MgAl}_{2} \mathrm{O}_{4}(\mathrm{~s}) \\
\Delta \mathrm{G}^{\circ}{ }_{973 \mathrm{~K}}=-7,69 \mathrm{kcal} / \mathrm{mol}
\end{gathered}
$$

(Zhong et al., 1995) performed an extensive bibliographical investigation on interfacial reactions occurring during the production of aluminium- $\mathrm{Al}_{2} \mathrm{O}_{3}$ fibers lined with $\mathrm{SiO}_{2}$ composites, with several initial $\mathrm{Mg}$ concentrations. They analysed experiments performed by other authors, who found that $\mathrm{MgAl}_{2} \mathrm{O}_{4}$ formed at the $\mathrm{Al}_{2} \mathrm{O}_{3}$ fiber interface contained an $\mathrm{Al}$ alloy with $4 \mathrm{wt}$. \% $\mathrm{Mg}$, at $800{ }^{\circ} \mathrm{C}$. (Fishkis, 1991) also confirmed the formation of $\mathrm{MgAl}_{2} \mathrm{O}_{4}$ at the interface of $\mathrm{Al}_{2} \mathrm{O}_{3}$ fibers lined with $\mathrm{SiO}_{2}$, embedded in an aluminium alloy containing 3 wt. \% Mg. However, in similar experiments performed by (Pai \& Ray, 1976) they found $\mathrm{MgO}$ as the main reaction product, although the alloys tested contained more than $4 \mathrm{wt} . \%$ $\mathrm{Mg}$. The proposed reaction is:

$$
\begin{gathered}
3 \mathrm{Mg}_{(\mathrm{Al})}+\mathrm{Al}_{2} \mathrm{O}_{3}(\mathrm{~s})=3 \mathrm{MgO}(\mathrm{s})+2 \mathrm{Al}(\mathrm{l}) \\
\Delta \mathrm{G}^{\circ}{ }_{973 \mathrm{~K}}=-28,63 \mathrm{kcal} / \mathrm{mol}
\end{gathered}
$$

(Pfeifer et al., 1990) found similar results to those reported by Pai et al. They accept the formation of $\mathrm{MgO}$ via the reaction given by equation (2), indicating that $\mathrm{MgO}$ could also be formed by direct reaction between dissolved $\mathrm{Mg}$ and $\mathrm{O}_{2}$ from the atmosphere, according to: 


$$
\begin{gathered}
2 \mathrm{Mg}_{(\mathrm{Al})}+\mathrm{O}_{2}=2 \mathrm{MgO}(\mathrm{s}) \\
\Delta \mathrm{G}^{\circ}{ }_{973 \mathrm{~K}}=-237,38 \mathrm{kcal} / \mathrm{mol}
\end{gathered}
$$

Note the high Gibbs free energy of this reaction. However, $\mathrm{O}_{2}$ is not soluble in molten aluminium, limiting the extent of such a reaction, as was established by (Campbell, 2003). (Lloyd et al., 1994) found that for Mg concentrations less than $3 \mathrm{wt}$. \%, the following reaction takes place:

$$
\begin{gathered}
\mathrm{Mg}_{(\mathrm{Al})}+4 / 3 \mathrm{Al}_{2} \mathrm{O}_{3}(\mathrm{~s})=\mathrm{MgAl}_{2} \mathrm{O}_{4}(\mathrm{~s})+2 / 3 \mathrm{Al}(\mathrm{l}) \\
\Delta \mathrm{G}^{\circ}{ }_{973 \mathrm{~K}}=-19,17 \mathrm{kcal} / \mathrm{mol}
\end{gathered}
$$

The reaction between the $\mathrm{SiO}_{2}$ of the lining material and $\mathrm{Mg}$ is given by:

$$
\begin{gathered}
\mathrm{SiO}_{2}(\mathrm{~s})+2 \mathrm{Mg}_{(\mathrm{Al})}=2 \mathrm{MgO}(\mathrm{s})+\mathrm{Si}_{(\mathrm{Al})} \\
\Delta \mathrm{G}^{\circ}{ }_{973 \mathrm{~K}}=-61,71 \mathrm{kcal} / \mathrm{mol}
\end{gathered}
$$

(Hallstedt et al., 1990) established the rate of diffusion of the $\mathrm{Al}^{+3}$ and $\mathrm{Mg}^{+2}$ cations through $\mathrm{MgO}$ and $\mathrm{MgAl}_{2} \mathrm{O}_{4}$, determining that diffusion through $\mathrm{MgAl}_{2} \mathrm{O}_{4}$ is up to ten orders of magnitude faster than through $\mathrm{MgO}$. Moreover, they found that the interfacial reactions between dissolved $\mathrm{Mg}$ and $\mathrm{SiO}_{2}$ stopped as the concentration of $\mathrm{Mg}$ increased, becoming negligible at $\mathrm{Mg}$ concentrations above $7 \mathrm{wt}$. \%. (Molins et al., 1991) characterised the interface between $\mathrm{Al}_{2} \mathrm{O}_{3}$ fibers lined with $\mathrm{SiO}_{2}$ and an alloy containing 3 wt. \% $\mathrm{Mg}$. They found not only $\mathrm{MgO}$, but also $\mathrm{MgAl}_{2} \mathrm{O}_{4}$, formed through the following chemical reaction:

$$
\begin{gathered}
\mathrm{Mg}_{(\mathrm{Al})}+2 \mathrm{Al}(\mathrm{l})+2 \mathrm{SiO}_{2}(\mathrm{~s})=\mathrm{MgAl}_{2} \mathrm{O}_{4}(\mathrm{~s})+2 \mathrm{Si}_{(\mathrm{Al})} \\
\Delta \mathrm{G}^{\circ}{ }_{973 \mathrm{~K}}=-98,01 \mathrm{kcal} / \mathrm{mol}
\end{gathered}
$$

After ageing the alloy at $500{ }^{\circ} \mathrm{C}$ for $6 \mathrm{~h}$, dissolved $\mathrm{Mg}$ reacted with the $\mathrm{SiO}_{2}$ of the $\mathrm{Al}_{2} \mathrm{O}_{3}$ fiber lining. Using transmission electron microscopy, these authors identified $\mathrm{Al}_{2} \mathrm{O}_{3}, \mathrm{MgO}$ and $\mathrm{MgAl}_{2} \mathrm{O}_{4}$ phases. Their results indicate that the chemical reactions in the solid state are slow enough to permit identification of the several oxides being formed. The results about the effect of initial $\mathrm{Mg}$ concentration on the nature of reaction products during the production of $\mathrm{Al}-\mathrm{Al}_{2} \mathrm{O}_{3}$ composites have been corroborated by (McLeod \& Gabryel, 1992), establishing that for a $\mathrm{Mg}$ concentration less than $3 \mathrm{wt}$ \%, the main reaction product will be $\mathrm{MgAl}_{2} \mathrm{O}_{4}$. They constructed an equilibrium diagram representing different situations similar to the one shown in Figure 1, and the utility of this diagram will be discussed later.

\section{Kinetic considerations for studying reaction mechanisms}

The thermodynamics of molten aluminium solutions for refining purposes have been studied for many years. Most of the important systems behave as ideal solutions at temperatures above $973 \mathrm{~K}$, so chemical refining methods can be used to remove elements such as $\mathrm{Ca}, \mathrm{K}, \mathrm{Mg}, \mathrm{Na}$, and $\mathrm{Sr}$, as shown in the works of (DiRusso, 1960), (Gruzleski \& Closset, 1990), (Gariepy \& Dube, 1984), and (Moore, 1990). On the other hand, alloying can be performed taking advantage of the aluminothermic reduction of oxides such as $\mathrm{CuO}$, $\mathrm{MnO}_{2}, \mathrm{FeO}$, and $\mathrm{SiO}_{2}$. Nowadays, software can be used to determine parameters such as the 


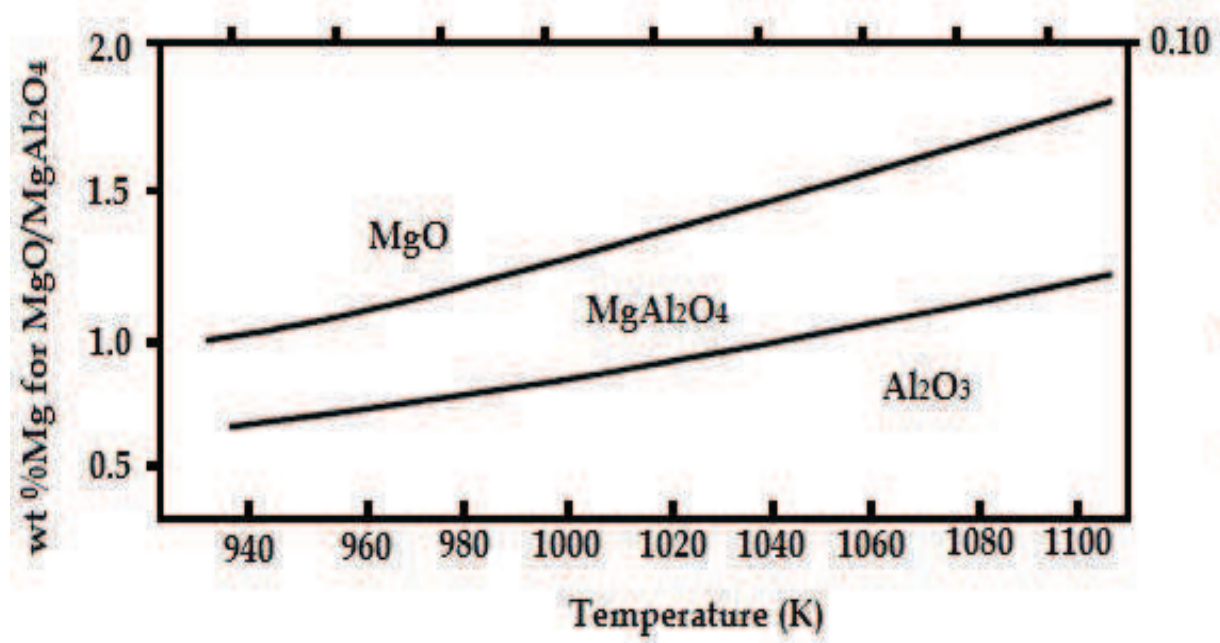

Fig. 1. Thermodynamic stability diagram of the oxides in molten Al-Mg alloys, (Mcleod \& Gabryel, 1992).

Gibbs free energy of reaction, chemical potential values, and activity coefficients, helping to understand how a system will behave in a given set of conditions such as temperature, pressure, and initial chemical composition. Special software has even been developed for multicomponent systems, such as the programs used by (Kattner, 1997) and Gröbner et al., 2002). Therefore, the utility of thermodynamic software is its ability to determine the Gibbs free energy of reaction of, for example, the aluminothermic reactions given by equations (1) through (6). Also, the following chemical reaction from the work of (Moreno, 2005) can be considered:

$$
\begin{gathered}
2 \mathrm{Sb}_{(\mathrm{Al})}+3 \mathrm{Ca}(\mathrm{s})=\mathrm{Ca}_{3} \mathrm{Sb}_{2}(\mathrm{~s}) \\
\Delta \mathrm{G}_{973 \mathrm{~K}}^{\circ}=-157.28 \mathrm{kcal}
\end{gathered}
$$

The formation of intermetallic phases once the reduced element dissolves first in the molten solution has been shown to lower the activity coefficient of $\mathrm{Sb}$, thus increasing the negative value of the Gibbs free energy of reaction, as shown by (Rajagopalan et al., 1999). It must also be considered that the use of a flux to remove the chemical compounds formed as slag can increase their activity coefficients, therefore augmenting the negative value of the Gibbs free energy.

Using mechanically added powders and agitation, studies by (Langlais, 1991), (Muñis et al., 2008), (López, 2006), and (Ayala, 2010) have demonstrated the ability of aluminothermic reactions to produce $\mathrm{Al}-\mathrm{Sr}$ and $\mathrm{Al}-\mathrm{Zr}$ alloys with different chemical compositions. The molten aluminium solutions in these experiments contained above $1 \mathrm{wt} . \% \mathrm{Mg}$, as this amount was observed to increase bath reactivity. This effect has been well-documented by (Langlais, 1991), as Mg lowers the superficial tension of aluminium and also possesses a greater chemical affinity for any element other than aluminium. These investigations reveal that the diffusion of magnesium from the bulk to the boundary layer is the kinetic controlling step, so the reactions kinetics are determined by parameters including the initial 
$\mathrm{Mg}$ concentration in the melt, temperature, powder size, particle residence time, and agitation speed.

Aluminothermic reduction reactions are analysed based on the following experimental observations described by (Levenspiel, 2002) and (Rosenquist, 1987):

a. The kinetics of heterogeneous chemical reactions are governed by one or more of the following kinetic steps:

1. Transport of the reactive species from the bulk to the boundary layer.

2. Chemical reaction at the interfaces between reactive molten metal particles.

3. Formation of reaction products.

4. Mass transfer through the layers of reaction products to the bulk.

b. Two different types of chemical reactions can occur during metallurgical refining processes: molten metal-gas and molten metal-solid reactions. Molten metal-solid reactions can occur during mechanical powder addition and agitation, and can consist of two different reactions:

1. Permanent contact reaction, which occurs at the interface of the reaction between the slag and the molten metal.

2. Transitory reaction, which occurs inside the molten metal between the particles discharged by the plume carrier gas-reactive powder and the molten metal.

The study of the interactions occurring between the reactive powders and the molten bath is quite complex. Nevertheless, some reaction zones have been determined, which are shown in Figure 1. The description of these zones comes from the work of (Macias \& Flores, 1999).

- Jet zone, just at the exit of the injection lance.

- Bubbling zone, composed of the injected powder particles and the carrier gas bubbles merging from the lance.

- Broke-up zone, where the carrier gas bubbles reach the slag and pass into the atmosphere.

- Slag zone.

- $\quad$ Dispersion zone, where the carrier gas bubbles and slag particles are dispersed.

- Intermediate zone, where the fluid becomes stagnant.

For the chemical refining reactions that will be described in this work, the kinetic model that best fits the experimental results is termed the "decreasing nucleus model", which is also useful for determining the mechanisms of the reactions taking place. The following heterogeneous chemical reactions are likely to occur between molten metal and the injected $\mathrm{SiO}_{2}$ particles:

$$
\begin{gathered}
\text { aA(fluid) }+\mathrm{bB}(\text { solid })=\text { fluid products } \\
\text { aA(fluid })+b B(\text { solid })=\text { solid products } \\
\text { aA(fluid })+b B(\text { solid })=\text { solid and fluid products }
\end{gathered}
$$

When the reactive particles contain a significant amount of impurities, or if the reaction product is rigid enough, particles sizes do not decrease during reaction, yielding the name of this kinetic process. In this process, the chemical reaction is carried out first at the particlemolten metal interface, instantly forming a reaction product layer. Then, the reaction zone moves inside the particle, until reaching complete conversion. Because of the differences in atomic size between the participant chemical species, this reaction results in a significant amount of porosity, ensuring diffusion in both directions for the reduced and oxidised 
species. Therefore, the complete chemical reaction occurs in the 4 different stages described above. These stages occur in series, so the slowest one governs the global reaction rate. In this way, 3 different reaction mechanisms could take place, as depicted numerically in Table I, which indicates the corresponding equations of conversion time versus particle radius and chemical composition at the boundary layer.

In this Table, $\tau$ is the value of total conversion time, $t$ is actual time, $r_{c}$ is the actual radius of the particle, $\mathrm{R}$ is the initial radius of the particle, and $X_{B}$ is the mole fraction of the diffusive species B. Generally speaking, because of the high temperature at which most pyrometallurgical refining processes of molten metals are performed, the reaction rate at the liquid-solid interface is high and does not constitute a limiting step. Thus, the velocity at which chemical species diffuse through the layers of reaction products constitutes the ratedetermining step. Each of the kinetic mechanisms described in Table I result in specific susceptibilities to the process variables such as temperature, powder size, stirring speed, initial chemical composition of the melt, residence time of the reactive particles inside the melt, etc., so a statistical analysis must be performed to determine the reaction mechanisms governing the reaction rate.

Even when refining is performed in a controlled atmosphere, it is not possible to avoid the dissolution in the melt of small amounts of nitrogen or oxygen. Therefore, some undesired chemical compounds can form mainly complex aluminates or nitrides, affecting the efficiency of the reaction.

\begin{tabular}{|l|c|}
\hline Stage & $\begin{array}{l}\mathrm{t} / \tau \text { ratio versus particle size and chemical } \\
\text { composition }\end{array}$ \\
\hline $\begin{array}{l}\text { Diffusion from the bulk to the boundary } \\
\text { layer }\end{array}$ & $\frac{t}{\tau}=1-\left(\frac{r_{c}}{R}\right)^{3}$ \\
\hline $\begin{array}{l}\text { Diffusion through the layer of reaction } \\
\text { products }\end{array}$ & $\frac{t}{\tau}=1-3\left(\frac{r_{c}}{R}\right)^{2}+2\left(\frac{r_{c}}{R}\right)^{3}$ \\
\hline Chemical reaction at the interface & $\frac{t}{\tau}=1-\frac{r_{c}}{R}=1-\left(1-X_{B}\right)^{1 / 3}$ \\
\hline
\end{tabular}

Table I. Controlling stages for the decreasing nucleus model, and the equations indicating equivalent complete reaction time.

The kinetics of heterogeneous chemical reactions has been studied for more than 100 years. However, advanced analytical tools such as electron back scatter diffraction (EBSD) in scanning electron microscopes have only recently permitted a proper assessment of the stoichiometry of the chemical reactions taking place. It is worth mentioning that before EBSD analysis existed, electron diffraction in the transmission electron microscope (TEM) was the most accurate technique to determine the crystallographic structure of unknown phases in a sample. Therefore, phase identification by EBSD is complementary to TEM analysis. Nevertheless, it is important to mention the differences between phase identification and phase verification, as several definitions could exist. The main difference between these terms is the number of candidate phases that must be analysed to determine the right phase. In the case of phase verification, the operator knows quite well the phases that are present in the sample, usually analysing less than 5 possible phases. In phase identification, the right phase is sought from a database of crystallographic compounds with no operator assistance. 
EBSD patterns contain a great amount of information on the crystalline structure of the sample, which can allow for the determination of the spatial group of a certain phase, such as the symmetry elements contained in the pattern. Therefore, the EBSD diffraction pattern is a fundamental vehicle for determining the phases present in a sample and for a deep analysis of reaction kinetics as described in the works of (Schwartz et al., 2009) and (Randle \& Engler, 2000).

\section{Electron backscatter diffraction in the scanning electron microscope.}

When an electron beam hits a metallic sample in the scanning electron microscope, several dispersion and interaction phenomena occur, producing various signals as shown in Figure 2. Backscattered electrons are used to form an image, for chemical analysis, or for crystallographic analysis of the volume studied. Crystallographic analysis is performed by evaluating the diffraction pattern, which is generated when the primary electrons are diffracted by the lattice planes of the crystals. To obtain the best signal conditions for the EBSD analysis, the surface of the sample must form a small angle $2 \Theta$ with the electron beam. Figure 3 also shows the classic diffraction analysis from the lattice planes, as described in the work of (Randle and Engler, 2000). Moreover, it shows that the $\Theta$ angles for which diffraction occurs depend on the wavelength $(\lambda)$ and the interplanar space of the dispersant phase, $d$.

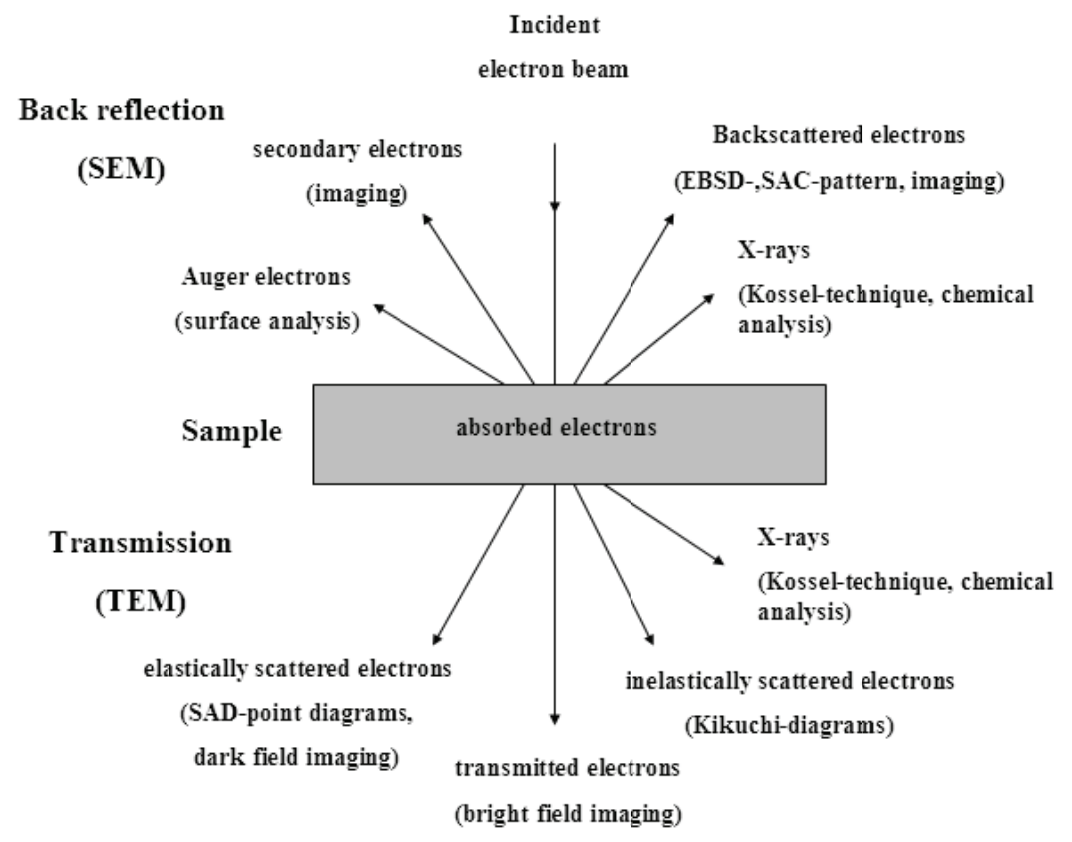

Fig. 2. Summary of the different signals generated due to the interaction of electrons with matter in a scanning electron microscope, as described in the work of (Randle \& Engler, 2000). 


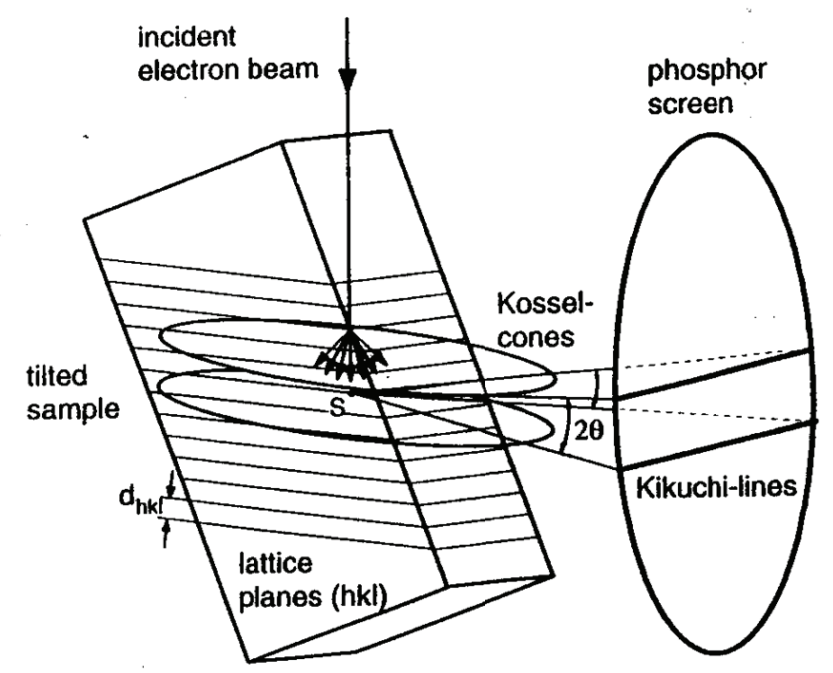

Fig. 3. Origin of Kikuchi lines from the perspective of EBSD, as described in the work of (Randle \& Engler, 2000).

Because electron diffraction through the Bragg $\Theta$ angle occurs in all directions, the diffracted beam is in the form of the surface of a cone, extending approximately from the normal plane to the reflecting atomic planes with a medium apical angle of $90-\Theta_{\mathrm{B}}$. In fact, considering that the source of electron dispersion lies between the lattice planes as shown in Figure 3, two cones of radiation are formed from each family of planes. Substituting the typical values of $\lambda$ and the interplanar space of the lattice $d$ into the Bragg equation, a $Q$ of $0.5^{\circ}$ is obtained. Therefore, the apical angle of a diffraction cone is approximately $180^{\circ}$, indicating that the cones are almost planar. When a phosphor screen of the camera in the EBSD analysis system is positioned such that it collects the diffraction cones, a pair of parallel conical sections are formed as a result, called Kikuchi lines. The sections are spaces at an angular $2 \Theta_{\mathrm{B}}$ distance, proportional to the interplanar spacing.

Having obtained a good EBSD pattern from a metallic sample, the next step is to determine the punctual chemical composition of a particle of interest. This is done in the scanning electron microscope using either energy dispersive spectroscopy (EDS) or wavelength dispersive spectroscopy (WDS) analysis, and is important to enable a search of the crystallographic phase databases. Then, the pairs of Kikuchi lines are identified using the Hough transformation to obtain points in a Hough space that can be located automatically. Moreover, the width of the lines can also be calculated. The width of a pair of Kikuchi lines is inversely proportional to the interplanar spacing of the atomic planes, and together the lines form a reduced volume of the unit cell. More than one volume element can be generated if more than three Kikuchi bands can be located. The unique property of the volume elements calculated in this way, starting from the EBSD pattern, is that when each volume element is multiplied by an enter, it reproduces the reduced volume of the lattice. Once the number of volume elements have been calculated, it is relatively simple to find the highest common multiple for the smaller volume elements. Then, it is necessary to search the available crystallographic charts. One of the most important crystallographic databases 
is that of the (International Crystallographic Diffraction Data, 2009), containing more than 100,000 different inorganic compounds.

Before describing the experimental evidence studied in this work, it is worth mentioning that the work in itself deals with the reaction kinetics of molten aluminium refining using EBSD to identify and therefore propose the numerical reaction rates governing $\mathrm{Mg}$ and $\mathrm{Sb}$ removal by $\mathrm{SiO}_{2}$ and $\mathrm{Ca}$, respectively. Extensive work has been conducted to measure the reaction rates of thousands of chemical reactions, so the fundamentals of such reactions are well established and are reported in several classical books such as those by (Levenspiel, 2002), (Rosenquist, 1987), (Szekely et al., 1971), and (Poirier \& Geiger, 1994). On the other hand, different analytical techniques continuously emerge, permitting a study of the phenomena occurring in deep molten metals. EBSD in an SEM has been useful not only for measuring reaction rates and determining the values of kinetic parameters, but also in determining the mechanism of reaction.

\section{Reaction kinetics of important aluminium systems; experimental part}

This part of the chapter will present the methodology used to assess the stoichiometry of the reaction occurring during the refining of $\mathrm{Mg}$ or $\mathrm{Sb}$ from molten aluminium by mechanically added powders and agitation of $\mathrm{SiO}_{2}$ and $\mathrm{Ca}$, respectively, using EBSD in an SEM as analytical techniques. To obtain samples for microscopic analysis, several experiments were conducted using an electrical resistance furnace with automatic temperature control as a melting unit, which contained a silicon carbide crucible and had a 4-kg molten aluminium capacity. A controlled velocity stirring device was coupled to the furnace to maintain $\mathrm{SiO}_{2}$ or Ca particles inside the melt. An average of $2.5 \mathrm{~kg}$ of molten alloy was used with the following initial chemical composition in weight percent: $9.50 \mathrm{Si}, 0.18 \mathrm{Fe}, 3.50 \mathrm{Cu}, 0.03 \mathrm{Mn}$, $1.18 \mathrm{Mg}, 0.30 \mathrm{Zn}$, and $0.08 \mathrm{Ti}$. Once the alloy melted and the temperature of interest was reached, i.e., $750{ }^{\circ} \mathrm{C}$, the stoichiometric amount of $\mathrm{SiO}_{2}$ or $\mathrm{Ca}$ was added to the center of the vortex formed by the impeller of the agitation system. In the case of $\mathrm{Sb}$ removal by $\mathrm{Ca}$, the initial chemical composition of the alloy was adjusted to $0.5 \mathrm{wt}$. \% Sb. The morphology of the added particles was irregular spherical, with a variable diameter between 0.15 and 0.22 mm. Agitation velocity was fixed at 120 r.p.m., which was kept constant during each experiment. The quantities of reactants were calculated according to the stoichiometry of reactions given by equations (6) and (7) and the amount of molten alloy. Reaction temperatures of 700, 725, 750 and $775{ }^{\circ} \mathrm{C}$ were studied, with stirring maintained for $60 \mathrm{~min}$. Samples from the melt were taken every minute during the first $10 \mathrm{~min}$, and every $5 \mathrm{~min}$ thereafter. The solidified samples were chemically analysed using plasma emission spectroscopy to determine the $\mathrm{Mg}$ or $\mathrm{Sb}$ concentrations as a function of sampling time at constant temperature. Part of each sample was metallographically prepared for observation in the SEM using a complementary combination of micropuntual structural analysis techniques such as EDS and EBSD. EBSD analysis requires a sample surface in very good condition to obtain Kikuchi lines with a suitable resolution. To obtain suitable samples, a vibratory polishing machine was used at $7200 \mathrm{~Hz}$ without vertical movement. Then, the samples were polished for 2 hours with nylon clothing discs impregnated with a solution of diamond paste in distilled water, with $1 \mu \mathrm{m}$ diamond particle sizes. Then, a third polishing step was applied for 2 hours using diamond paste with a $0.25 \mu \mathrm{m}$ particle size. Final polishing was performed using macrocloth discs mounted over a static plate using colloidal silica as an abrasive at $\mathrm{pH}$ 9.8. This technique was very useful for the identification of 
reaction products formed by the chemical reactions taking place and their main structural characteristics. Also, the width of the layers of reaction products was measured, and those values were used in the following analysis of the reaction kinetics. In these cases, confidence levels of EBSD analysis of 0.7 were chosen to ensure excellent identification.

\subsection{Kinetics of antimony removal from molten aluminium by $\mathrm{Ca}$ addition}

First, after the addition of calcium the antimony-containing aluminium alloy, a removal reaction occurs over time, as seen in Figure 4 . As much as $85.2 \%$ of antimony was removed after 40 minutes of reaction. The morphology and size of antimony and calcium-rich particles are shown in the SEM micrograph of Figure 5, together with the corresponding EDS patterns.

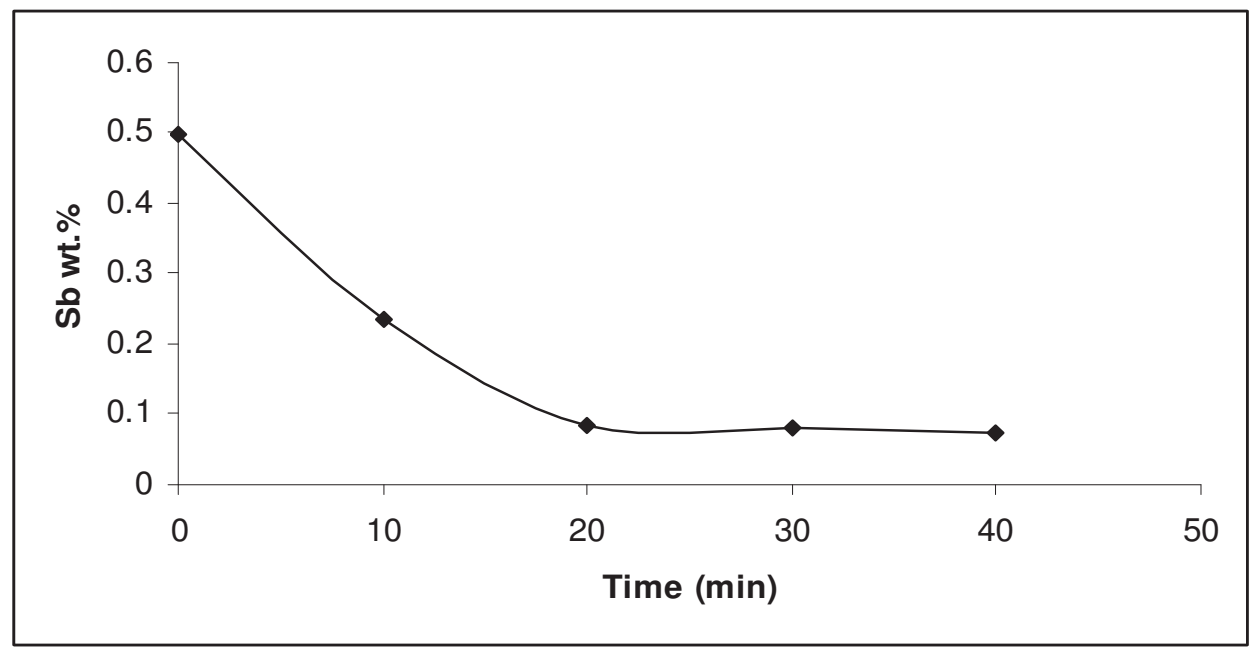

Fig. 4. Rate of antimony removal from molten aluminium after calcium addition, at $750 \circ \mathrm{C}$.

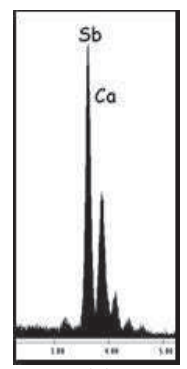

(a)

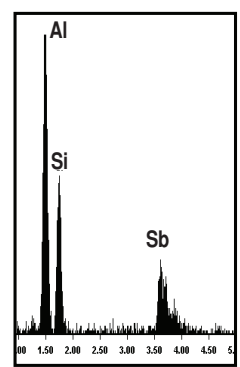

(b)

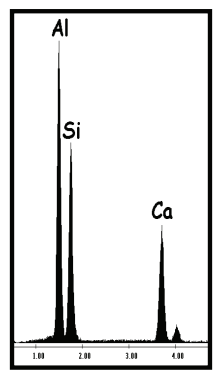

(c)

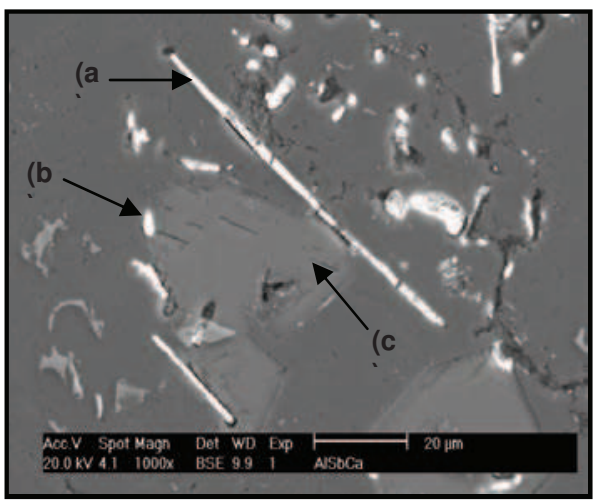

Fig. 5. EDS patterns of; a), Sb-Ca; b), Al-Si-Sb; and c), Al-Si-Ca rich particles, and SEM micrograph of the analyzed area. 
a)

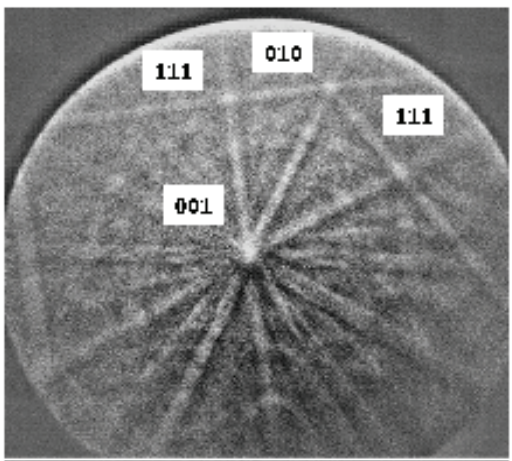

b)

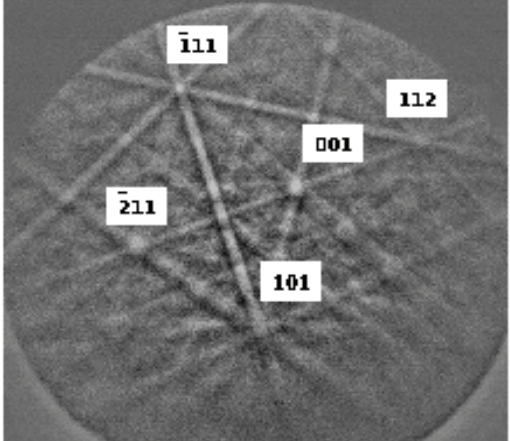

Fig. 6. EBSD patterns and their corresponding indexing for the (a), $\mathrm{Ca}_{2} \mathrm{Sb}$; and (b), $\mathrm{AlSb}$ phases.

However, when EBSD was used, the $\mathrm{Ca}_{2} \mathrm{Sb}$, and $\mathrm{AlSb}$ phases were identified, as shown in Figure 6 . These results indicate that the antimony removal reaction is as follows:

$$
\mathrm{Sb}(\mathrm{Al})+2 \mathrm{Ca}=\mathrm{Ca}_{2} \mathrm{Sb}(\mathrm{s})+\mathrm{Al}
$$

The SEM micrograph shown in Figure 7 demonstrates that the $\mathrm{Ca}_{2} \mathrm{Sb}$ phase is of predendritic nature, i.e., the particles are formed while the molten alloy is still at high temperature. Upon solidification, these particles grow over the aluminium grain boundaries, acquiring a needle-like morphology, reaching a maximum length of $50 \mu \mathrm{m}$. Although very small particles on the order of $5 \mu \mathrm{m}$ were also observed, because of their density $(3.72 \mathrm{~g} / \mathrm{ml})$ is higher than that of aluminium, the particles will tend to settle down in the molten metal. On the other hand, a close relationship has been observed between particles of $\mathrm{Ca}_{2} \mathrm{Sb}$ and those containing $\mathrm{Al}, \mathrm{Ca}$, and $\mathrm{Si}$, although it was not possible to determine the crystallographic characteristics of those particles by EBSD. Apart from the lack of availability of cards containing the crystallographic characteristics of ternary Al-Ca$\mathrm{Sb}$ phases, no Al-Ca-Sb or Al-Si-Sb equilibrium diagrams are available.

\section{Kinetics of the removal of magnesium from molten aluminium by the addition of $\mathrm{SiO}_{2}$}

Figure 8 shows a partially reacted $\mathrm{SiO}_{2}$ particle that has been immersed in molten aluminium for 1 minute at $750{ }^{\circ} \mathrm{C}$. The central part of this micrograph shows the corresponding EDS pattern. The EBSD patterns shown in the upper part of this micrograph are characteristic of the $\mathrm{SiO}_{2}$ and $\mathrm{MgAl}_{2} \mathrm{O}_{4}$ phases. 

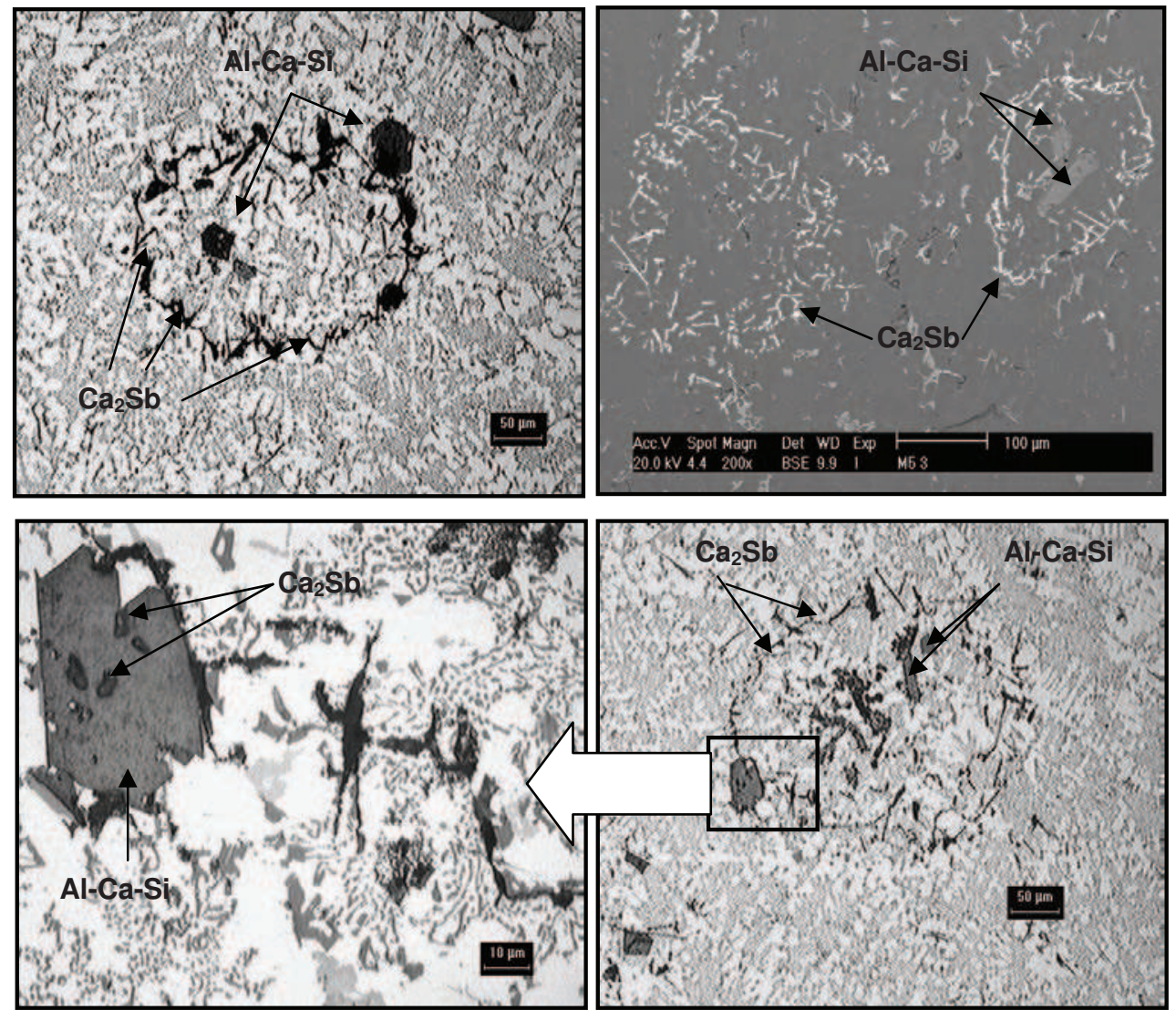

Fig. 7. Microstructural features of $\mathrm{AlCaSi}$ and $\mathrm{CaSb}$ particles after calcium addition to AlSb alloys.

A line scan analysis was performed in the SEM to obtain information about the distribution of elements at the interface solid $\left(\mathrm{SiO}_{2}\right)$-melt phase, as well as over the layers of reaction products. At least 10 particles per sample were measured for this analysis. Figure 9 shows typical results for a particle analysed after it was immersed for 1 minute in molten aluminium at $750{ }^{\circ} \mathrm{C}$. Similar analyses were performed for particles immersed for longer periods of time.

These results indicate that the $\mathrm{SiO}_{2}$ reduction reactions occurring during $\mathrm{Mg}$ refining of molten aluminium leading to $\mathrm{MgAl}_{2} \mathrm{O}_{4}$ formation occur immediately once the particles come into contact with molten aluminium. Therefore, we conclude that the formation of $\mathrm{MgAl}_{2} \mathrm{O}_{4}$ occurs faster than the other phases because no evidence was found of the formation of $\mathrm{MgO}$ or $\mathrm{Al}_{2} \mathrm{O}_{3}$, as demonstrated by the Gibbs free energy:

$$
\begin{gathered}
2 \mathrm{Al}(\mathrm{l})+3 / 2 \mathrm{SiO}_{2}(\mathrm{~s})=\mathrm{Al}_{2} \mathrm{O}_{3}(\mathrm{~s})+3 / 2 \mathrm{Si}_{(\mathrm{Al})} \\
\Delta \mathrm{G}_{973 \mathrm{~K}}^{\circ}=-63,86 \mathrm{kcal} / \mathrm{mol}
\end{gathered}
$$



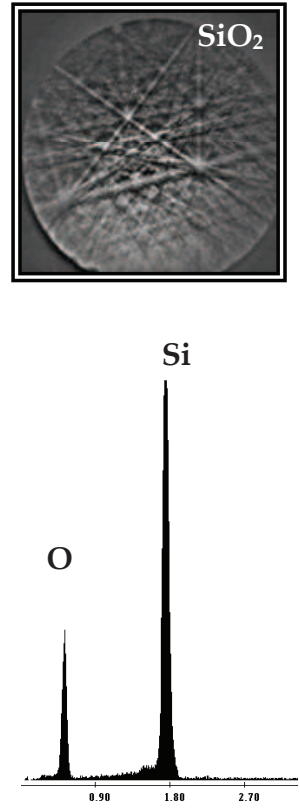

(a)

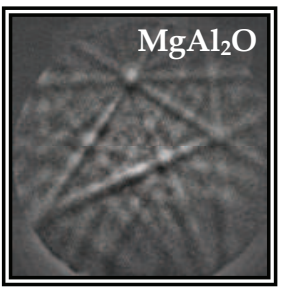

Al

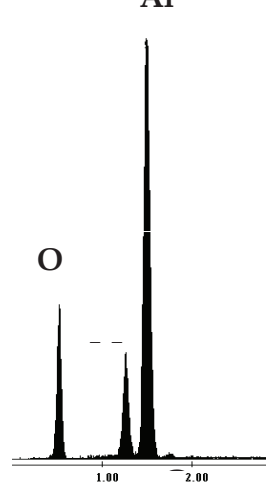

(c)

Fig. 8. (a), EDS and EBSD patterns of $\mathrm{SiO}_{2}$ particles; (b), SEM micrograph of the particles, and (c), EDS and EBSD patterns of the $\mathrm{MgAl}_{2} \mathrm{O}_{4}$ layer of reaction products. The micrographs correspond to a particle that has been reacting in the molten bath for 1 minute at $750{ }^{\circ} \mathrm{C}$.

Figure 10 shows the variation of $\mathrm{Mg}$ concentration as a function of time at $750{ }^{\circ} \mathrm{C}$. This graph shows that $\mathrm{Mg}$ concentration diminishes continuously until reaching a constant value at constant temperature.

For reaction times less than 5 minutes, only $\mathrm{Al}_{2} \mathrm{O}_{3}, \mathrm{MgAl}_{2} \mathrm{O}_{4}$ and $\mathrm{Si}$ were formed as reaction products. However, $\mathrm{SiO}_{2}$ nuclei still persist under these conditions. The micrograph in Figure 11a) shows the EDS and EBSD patterns of the nucleus of a $\mathrm{SiO}_{2}$ particle that was immersed for 5 minutes in molten aluminium at $750{ }^{\circ} \mathrm{C}$, where Fig. 11b) shows the partially reacted $\mathrm{SiO}_{2}$ particle. Finally, Fig. 11c) shows the EDS and EBSD patterns of the $\mathrm{MgAl}_{2} \mathrm{O}_{4}$ in the layer of reaction products. According to (Zhong et al., 2003), the layers of reaction products will grow until the $\mathrm{Mg}^{+2}$ ions in the melt are depleted. Complete conversion of the $\mathrm{SiO}_{2}$ nucleus into reacted products occurs after $60 \mathrm{~min}$, and the conversion is closely related to $\mathrm{Mg}$ depletion as shown in Fig. 10.

Figure 12 shows the $\mathrm{SiO}_{2}$-melt interface of a particle that was immersed for 10 minutes at $750{ }^{\circ} \mathrm{C}$, where the $\mathrm{SiO}_{2}$ nucleus still exists. A layer of $\mathrm{Al}_{2} \mathrm{O}_{3}$ adjacent to the nucleus and an external thin layer of $\mathrm{MgAl}_{2} \mathrm{O}_{4}$ are also observed. The increase in the amount of $\mathrm{Al}_{2} \mathrm{O}_{3}$ instead of $\mathrm{MgAl}_{2} \mathrm{O}_{4}$ can be explained in terms of the depletion of $\mathrm{Mg}$ from the melt and over the boundary layer, as $\mathrm{Mg}$ depletion also affects the amount of $\mathrm{MgO}$ that could be formed. On the contrary, as $\mathrm{Al}$ concentration is always constant at the boundary layer, it is always diffusing through the pores in the layers of reaction products. According to the stability of oxides in the Al-Mg-O $\mathrm{O}_{2}$ system (31) shown in Figure 1, below 0.49 wt. \% $\mathrm{Mg}$, the $\mathrm{Al}_{2} \mathrm{O}_{3}$ phase 


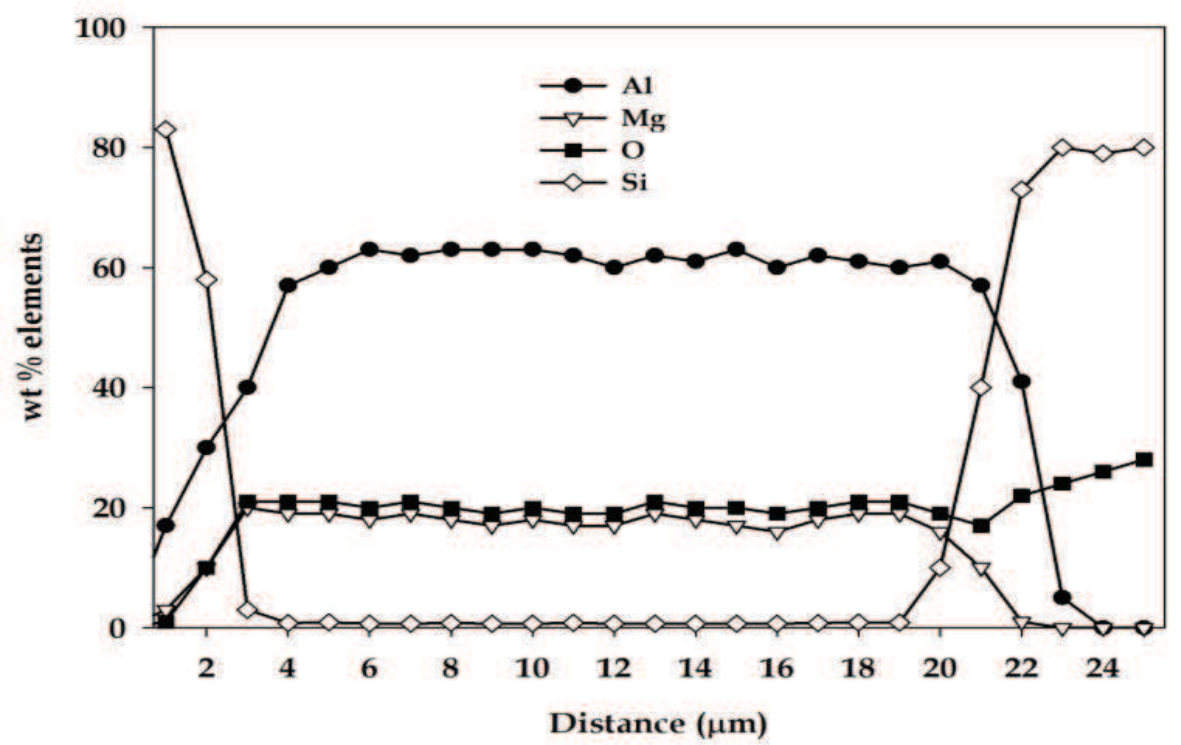

Fig. 9. Elemental distribution through the particle shown in Figure 8.

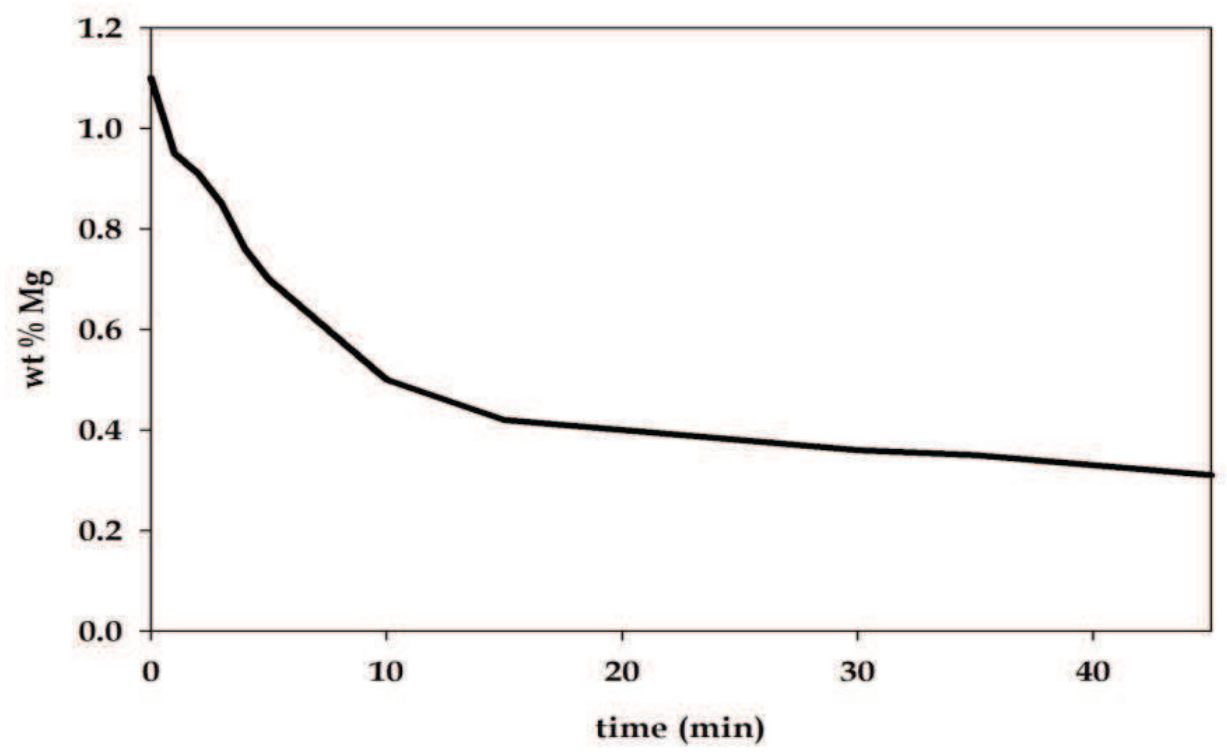

Fig. 10. Variation of $\mathrm{Mg}$ concentration as a function of time during $\mathrm{SiO}_{2}$ particle addition with mechanical agitation at $750{ }^{\circ} \mathrm{C}$. 


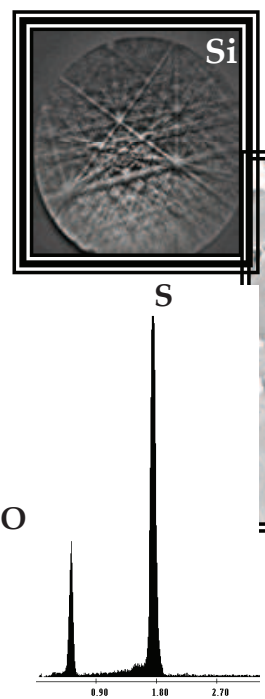

(a)

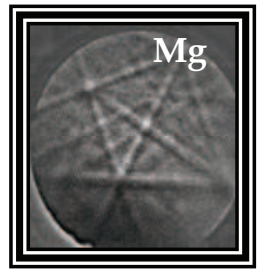

A

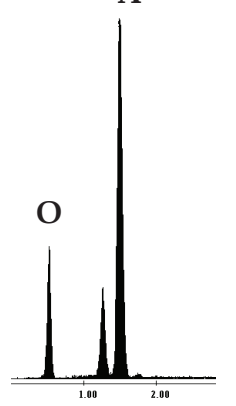

(c)

Fig. 11. (a), EDS and EBSD patterns of the nucleus of a $\mathrm{SiO}_{2}$ particle reacted for 5 minutes at $750{ }^{\circ} \mathrm{C}$ in molten aluminium; (b), SEM micrograph of the particle; and (c), EDS and EBSD patterns of $\mathrm{MgAl}_{2} \mathrm{O}_{4}$ in the layers of reaction products.
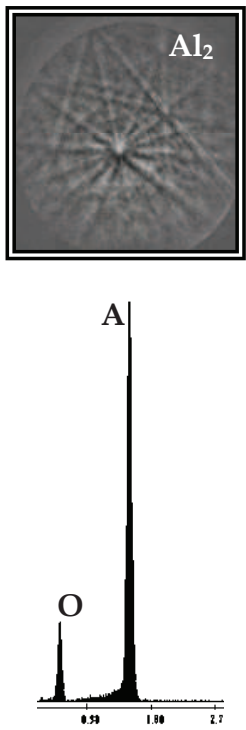

(a)

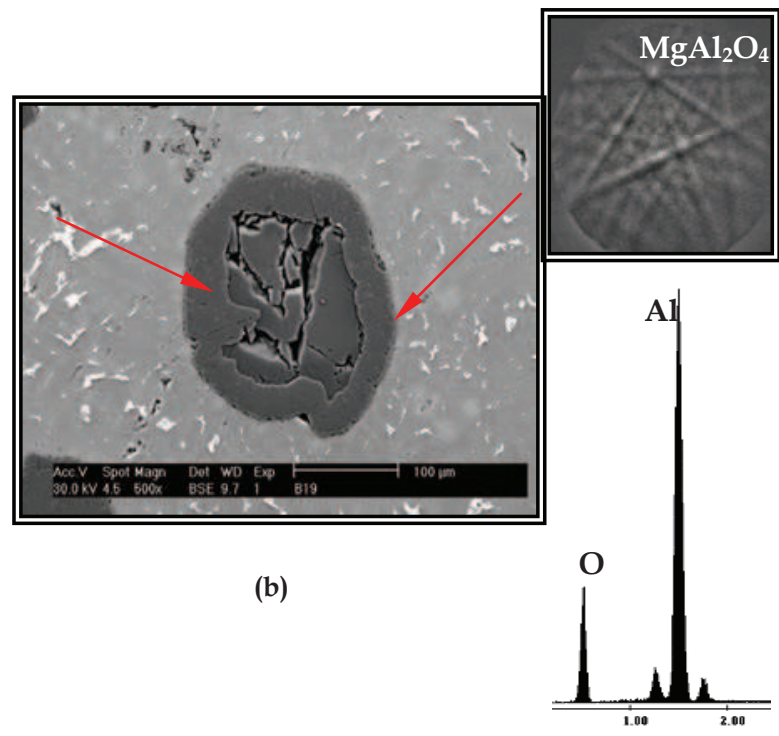

(c)

Fig. 12. (a), EDS and EBSD patterns of $\mathrm{Al}_{2} \mathrm{O}_{3}$ around the nucleus of $\mathrm{SiO}_{2}$ particle reacted for 10 minutes at $750{ }^{\circ} \mathrm{C}$ in molten aluminium; (b), SEM micrograph of the particle; and (c), EDS and EBSD patterns of $\mathrm{MgAl}_{2} \mathrm{O}_{4}$ in the outer layers of reaction products. 
is stable over the complete range of temperatures studied here, indicating the dissolution of $\mathrm{MgO}$. This demonstrates that reactions given by equations (5) and (10) occurred. Finally, particles that were immersed for more than 20 minutes at any temperature consisted basically of an $\mathrm{Al}_{2} \mathrm{O}_{3}$ nucleus surrounded by a thin layer of $\mathrm{MgAl}_{2} \mathrm{O}_{4}$ at the outer layer.

According to the results presented in the former analysis, the conversion rate of the $\mathrm{SiO}_{2}$ particles into reaction products can be followed using the unreacted nucleus model, considering spherical particles of constant size. The control stage could be the diffusion of reactants through the layers of reaction products, or chemical reaction. The time at which the diameter of the nucleus becomes zero can be determined experimentally is calculated with the following equation:

$$
\tau=\frac{a \rho_{\text {slag }} R_{p}^{2}}{24 \rho_{A l} D_{e f e c} C_{M g}}
$$

where,

$\tau=$ total conversion time of a particle (sec).

$\mathrm{a}=$ stoichiometric factor depending on the chemical reaction considered.

$\rho_{\text {slag }}=$ slag density $\left(\mathrm{kg} \cdot \mathrm{m}^{-3}\right)$.

$\mathrm{R}_{p}=$ average particle radius (m).

$\rho_{A l}=$ aluminium density $\left(\mathrm{kg} \cdot \mathrm{m}^{-3}\right)$.

$\mathrm{D}_{\text {effec }}=$ effective diffusion coefficient of $\mathrm{Mg}$ through the layers of reaction products $\left(\mathrm{m}^{2} \cdot \mathrm{s}^{-1}\right)$.

$\mathrm{C}_{\mathrm{Mg}}=$ actual $\mathrm{Mg}$ concentration at the solid $\mathrm{SiO}_{2}$-melt interface $\left(\mathrm{mol} \cdot \mathrm{m}^{-3}\right)$.

Data extracted from Figure 9 can be used to calculate the values of the $r_{c} / R$ and $t / \tau$ ratios. Furthermore, the dependence between these ratios can be determined to establish the kinetic control stage. Figure 13 shows this dependence at $750{ }^{\circ} \mathrm{C}$. According to the shape of the curve of this figure, the controlling kinetic step is the diffusion of $\mathrm{Mg}$ and $\mathrm{Al}$ through the layers of reaction products. If the chemical reaction was the kinetic controlling step, the shape of the graph should be a straight line between the $r_{c} / R=1,0$ and $t / \tau=1,0$ points.

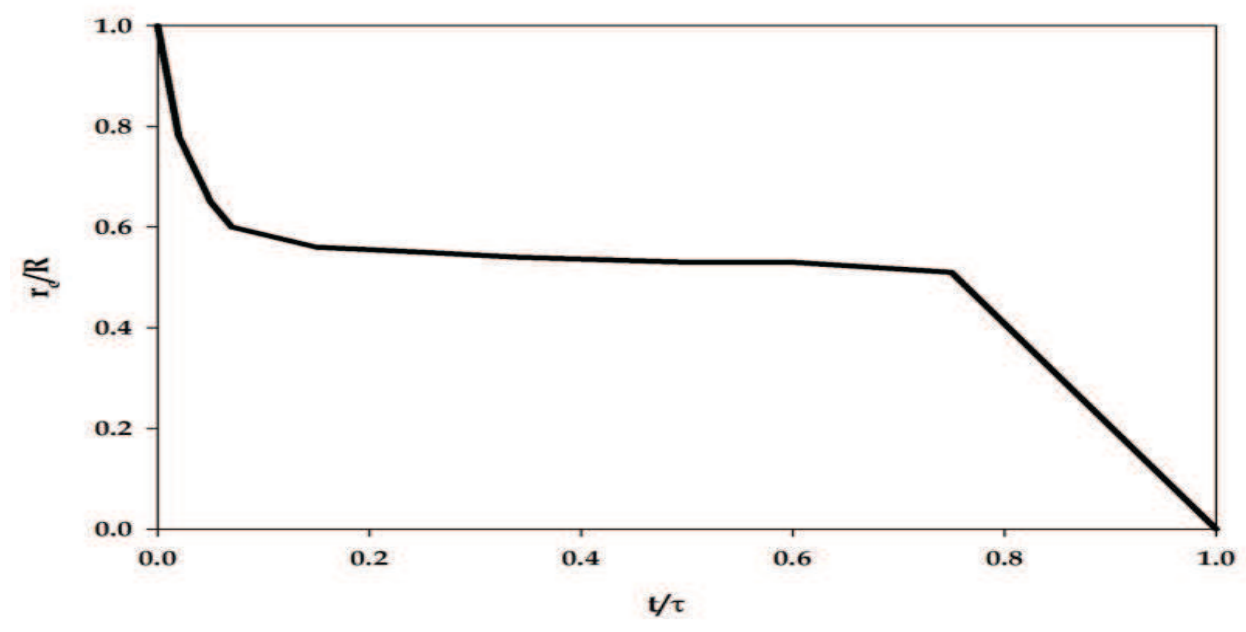

Fig. 13. Graphic representation of the dependence of $r_{c} / R$ vs. $t / \tau$ for the conversion of an $\mathrm{SiO}_{2}$ particle into reaction products at $750^{\circ} \mathrm{C}$. 
Regarding the mechanisms of reaction in the $\mathrm{SiO}_{2}$-melt system studied here, the most accurate explanation is that given by (Zhong et al. 2003), who states that the formation of $\mathrm{MgAl}_{2} \mathrm{O}_{4}$ is strongly dependent on the initial $\mathrm{Mg}$ concentration, as has been thermodynamically calculated and experimentally demonstrated in this work. Therefore, for initial $\mathrm{Mg}$ concentrations below $3 \mathrm{wt}$ \%, the stable phase in the range of temperatures from 700 to $850{ }^{\circ} \mathrm{C}$ is $\mathrm{MgAl}_{2} \mathrm{O}_{4}$, a situation that can be corroborated by observing Figure 1 . However, the reaction between $\mathrm{SiO}_{2}$ particles and magnesium dissolved in molten aluminium will be the most favourable, as indicated by the global reaction given by equation (6). The presence of $\mathrm{MgO}$ was not confirmed in this work, and according to the literature cited, this phase could occur only for higher initial $\mathrm{Mg}$ concentrations, i.e., above 3.5 wt. \%. Nevertheless, this concentration is easily attained at the solid $\mathrm{SiO}_{2}$-melt interface, specifically at the early time points following particle addition, ensuring the formation of a significant amount of $\mathrm{MgO}$. In turn, most $\mathrm{MgO}$ is consumed by the $\mathrm{MgAl}_{2} \mathrm{O}_{4}$ formation reaction.

Some studies have established that the reaction between dissolved $\mathrm{Mg}$ and $\mathrm{SiO}_{2}$ particles takes places rapidly as it can be difficult to determine the nucleation stage of $\mathrm{MgO}$ particles. (Molins et al., 1991) studied the interfacial reaction between a molten $\mathrm{Al}_{4} \mathrm{Mg}$ alloy and $\mathrm{Al}_{2} \mathrm{O}_{3}$ fibers, and showed that the $\mathrm{MgO}$ nucleus remain very small, forming thin layers of about 10 nanometers thickness. The diffusion of $\mathrm{Mg}^{2+}$ cations therefore occurs through the grain boundaries of $\mathrm{MgO}$ particles by an infiltration mechanism. The growth process of $\mathrm{MgO}$ layers continues until the grains around the interface matrix/reaction zone are large enough to close the intergranular spaces. Hence, the rate-determining step must be the diffusion of chemical species through the layers of reaction products.

The Gibbs free energy of reaction given by equation (10) indicates that the reduction of $\mathrm{SiO}_{2}$ by $\mathrm{Al}$ also occurs, as the $\mathrm{Al}^{+3}$ cations can diffuse through the spaces left by the released $\mathrm{Si}$. Silicon back-diffusion occurs through the grain boundaries of $\mathrm{MgO}$ and $\mathrm{Al}_{2} \mathrm{O}_{3}$, and $\mathrm{Si}$ dissolves in the molten aluminium phase. On solidification, $\mathrm{Si}$ is rejected from the solid solution, remaining as large crystals around foreign particles.

When the stoichiometric amounts of $\mathrm{MgO}$ and $\mathrm{Al}_{2} \mathrm{O}_{3}$ are reached and the equilibrium conditions indicated in Figure 1 are obeyed, the reaction given by equation (1) takes place. In this way, the formation of $\mathrm{MgAl}_{2} \mathrm{O}_{4}$ and the interdiffusion of $\mathrm{Al}^{+3}, \mathrm{Mg}^{+2}$ and $\mathrm{Si}^{+4}$ cations occur simultaneously. Once the $\mathrm{Mg}$ concentration in the molten alloy falls below $0.30 \mathrm{wt}$. \%, aluminium continues to react with the $\mathrm{SiO}_{2}$ nucleus, forming more $\mathrm{Al}_{2} \mathrm{O}_{3}$ at a constant growth rate controlled by the diffusion of $\mathrm{Al}^{+3}$ cations through the layers of reaction products. In turn, the small amount of $\mathrm{MgO}$ that can be formed through the reaction of $\mathrm{Mg}^{+2}$ cations with $\mathrm{SiO}_{2}$ is dissolved in the $\mathrm{Al}_{2} \mathrm{O}_{3}$ phase, as shown in Figure 1.

Reactions among molten aluminium and dissolved magnesium with solid $\mathrm{SiO}_{2}$ require the diffusion of ions, although the diffusion of $\mathrm{O}^{-2}$ ions is negligible because of their larger ionic size. The relationship among ionic radii of $\mathrm{Mg}^{+2}, \mathrm{Al}^{+3}$, and $\mathrm{Si}^{+4}$ with respect to $\mathrm{O}^{-2}$ is 0.47 , 0.34 and 0.28 , respectively, as shown by (Zhong et al., 2003). Therefore, the interdiffusion of $\mathrm{Mg}^{+2}$ and $\mathrm{Al}^{+3}$ cations is kinetically possible through the lattice in the structure of $\mathrm{SiO}_{2}$ of the $\mathrm{O}^{-2}$ anions, or through the $\mathrm{Si}^{+4}$ cations resulting from the $\mathrm{SiO}_{2}$ decomposition. Such reactions are given by:

$$
\begin{aligned}
\mathrm{Mg}^{\mathrm{O}}-2 \mathrm{e}- & =\mathrm{Mg}^{+2} \\
2\left(\mathrm{Al}^{\mathrm{o}}-3 \mathrm{e}-\right. & =2 \mathrm{Al}^{+3}
\end{aligned}
$$




$$
2\left(\mathrm{Si}+4+4 \mathrm{e}^{-}\right)=2 \mathrm{Si}^{\mathrm{o}}
$$

When the $\mathrm{Mg}^{+2}$ cations occupy interstitial sites inside the $\mathrm{SiO}_{2}$ lattice, the positions of $\mathrm{O}^{-2}$ anions must be adjusted to retain electrical neutrality and diminish the distortion energy of the lattice. The result is a change in crystal structure. The processes involved in this phenomenon are governed by the chemical potential values of the partial reactions, in this case, those given by reactions (5) or (10). As $\mathrm{MgAl}_{2} \mathrm{O}_{4}$ is the final reaction product, the reaction given by global equation (6) could be accepted, as this satisfies the described mechanism of reaction. However, to minimise interfacial energy, $\mathrm{MgAl}_{2} \mathrm{O}_{4}$ must form intermediate reaction products as follows. This situation can be represented in the stoichiometric form $x M g O-y \mathrm{Al}_{2} \mathrm{O}_{3}$, so when $\mathrm{x}=1$ and $\mathrm{y}=13$, the formula will be $\mathrm{MgAl}_{26} \mathrm{O}_{40}$; when $\mathrm{x}=1$ and $\mathrm{y}=1$, the formula will be $\mathrm{MgAl}_{2} \mathrm{O}_{4}$ (stoichiometric); when $\mathrm{x}=1$ and $\mathrm{y}=0$, the formula will be $\mathrm{MgO}$. Moreover, the relationship $\mathrm{x}-\mathrm{y}$ of $\mathrm{MgAl}_{2} \mathrm{O}_{4}$ ensures electrical neutrality in the oxide phase.

A kinetic condition necessary for diffusion of chemical species is continuous nanoporosity in the layers of reaction products. (Zhong et al., 2003) have determined that the formation of $\mathrm{MgO}$ over $\mathrm{SiO}_{2}$ particles involves a volume contraction of $13.6 \%$, whereas the formation of $\mathrm{MgAl}_{2} \mathrm{O}_{4}$ over $\mathrm{SiO}_{2}$ particles causes a volume contraction of $27 \%$. Because of these changes, the new phases formed break their unions with the original $\mathrm{SiO}_{2}$ particles instantly, transforming into thousands of small crystals, producing the necessary voids required for the diffusion of chemical species. This breaking-up is continuous, occurring together with the nucleation and growth of new phases over the former phases. However, for the last stages of $\mathrm{SiO}_{2}$ chemical reduction by $\mathrm{Mg}$ or $\mathrm{Al}$, the mechanism of reaction abruptly changes, as the concentration of $\mathrm{Mg}$ at the reaction interface lies below $0.3 \mathrm{wt}$. \%. At this time, the $\mathrm{MgO}$ that is formed dissolves in $\mathrm{Al}_{2} \mathrm{O}_{3}$. Then, these $\mathrm{Al}_{2} \mathrm{O}_{3}$ crystals grow continuously until reaching a micron size, closing the spaces for diffusion and thus stopping the chemical reaction underway.

The above explanations are important from the technological point of view, as unreacted $\mathrm{SiO}_{2}$ particles can remain entrapped in the molten metal as inclusions. On the other hand, knowing the true nature of the reaction products and the way that the stoichiometry of reaction changes as a function of $\mathrm{Mg}$ concentration in the melt and at the reaction interface, could be useful for developing specific types of fluxes for removing these particles. Of course, reaction kinetics could be accelerated, diminishing the size of the nucleus of $\mathrm{SiO}_{2}$ particles added for $\mathrm{Mg}$ refining from molten aluminium.

\subsection{Kinetic study}

According to classical kinetic theory (differential method), the rate of magnesium removal by $\mathrm{SiO}_{2}$ particle addition could be calculated by the following formula:

$$
-V \frac{d C_{M g}}{d t}=K\left(C_{M g}-C_{M g(e q)}\right)^{n} S_{p}
$$

where:

$\mathrm{C}_{\mathrm{Mg}}=$ actual concentration of $\mathrm{Mg}$ in the bath at constant temperature (wt. \%)

$\mathrm{C}_{\mathrm{Mg}(\mathrm{eq})}=\mathrm{Mg}$ concentration in the bath, at equilibrium, at constant temperature (wt. \%)

$\mathrm{K}=$ reaction rate constant $\left(\mathrm{cm}-(\mathrm{wt} . \%)^{1-\mathrm{r}} / \mathrm{s}\right)$

$\mathrm{t}=$ time $(\mathrm{s})$

$\mathrm{n}=$ order of reaction 
$\mathrm{Sp}=$ total area of reaction $\left(\mathrm{cm}^{2}\right)$

$\mathrm{V}=$ volume of the bath $\left(\mathrm{cm}^{3}\right)$

Equation (15) can be simplified considering that the value of $\mathrm{C}_{\mathrm{Mg}(\mathrm{eq})}$ is close to zero in the range of temperature under study. The value of $K_{p}$ captures the effects of particle size and the volume of the bath, so equation (15) could be rewritten as follows:

$$
-\frac{d C_{M g}}{d t}=K_{p}\left(C_{M g}\right)^{n}
$$

This equation can be transformed into a linear equation of the form:

$$
-\ln \left[\frac{d C_{M g}}{d t}\right]=n \ln \left(C_{M g}\right)+\ln \left(-K_{p}\right)
$$

The order of reaction $\mathrm{n}$ can be obtained from experimental results through a linear graph of $\ln \left(\mathrm{dC}_{\mathrm{mg}} / \mathrm{dt}\right)$ vs. $\ln \left(\mathrm{C}_{\mathrm{Mg}}\right)$. The works conducted by (Flores et al., 1998) and (Escobedo et al., 2003) showed that the value of $n$ is close to 1 . The values of $K_{p}$ for every temperature are directly obtained from the $y$-intercept of the straight line. In finding an analytical solution of equation (16), considering that the value of $\mathrm{n}$ is equal 1 , the following expression is obtained:

$$
C_{M g}=C^{o}{ }_{M g} \exp \left\lfloor\left(-K_{p}\right) t\right\rfloor
$$

The value of $K_{p}$ can be used to obtain the activation energy of the process through the following Arrhenius-type expression:

$$
K_{p}=A e^{-Q / R T}
$$

where:

$\mathrm{A}=$ Frequency factor

$\mathrm{Q}=$ activation energy (joule $/ \mathrm{mol}$ )

$\mathrm{R}=$ universal gas constant (joule/mol-K)

$\mathrm{T}=$ temperature $(\mathrm{K})$

This expression must be transformed into a linear one, yielding the following equation:

$$
K_{p}=\ln A-Q / R T
$$

The slope of a linear graph of $\ln \left(\mathrm{K}_{\mathrm{p}}\right)$ versus $1 / \mathrm{RT}$ is used to determine the value of activation energy, whereas the $y$-intercept of the straight line is the value of $\ln (\mathrm{A})$. (Macias \& Flores, 1999) measured the activation energy of the Mg removal process using solid fluxes, reporting that this process requires $11540 \mathrm{cal} / \mathrm{mol}$. This value is close to typical values obtained for diffusion-controlled metallurgical processes.

\section{Conclusions}

Antimony was removed from molten aluminium by adding powders of a master calciumaluminium alloy, with as much as 85.2 wt. \% of the initial Sb removed. The compounds formed after calcium addition were identified using electron backscattered diffraction in a scanning electron microscope, identifying phases such as the intermetallic compound $\mathrm{Ca}_{2} \mathrm{Sb}$. 
The chemical reaction between magnesium dissolved in molten aluminium and $\mathrm{SiO}_{2}$ particles reacts according to a mechanism where the diffusion of $\mathrm{Al}^{+3}, \mathrm{Mg}^{+2}$, and $\mathrm{Si}^{+4}$ ions through the porosity of the layers of reaction products determines the reaction kinetics. EBSD determined the true nature of the reaction products, demonstrating the formation of $\mathrm{MgAl}_{2} \mathrm{O}_{4}$ and $\mathrm{Al}_{2} \mathrm{O}_{3}$ over former $\mathrm{SiO}_{2}$ nuclei.

Future work must focus on studying the effect of powder size, temperatures above $800{ }^{\circ} \mathrm{C}$, and enhanced agitation conditions on the reaction rate in the systems studied. These findings are important for the commercial production of inclusion-free high-quality Al-Si$\mathrm{Cu}$ alloys.

\section{References}

American Society for Metals (1988). Metals Handbook Vol. 15: Casting, 9th Ed. ISBN-0-87170007-7. USA. pp. 55-60.

Ayala, Z. (2010). Análisis Cinético de la Obtención de Aleaciones Maestras Al-Zr, Mediante la reducción Aluminotérmica del $\mathrm{ZrO}_{2}$. Master's Thesis, CINVESTAV Saltillo, México.

Campbell, J. (2003). Castings. 2nd Ed. Butterwoth-Heinemann Linacre House. pp. 4-5. ISBN-07506-4790-6. Oxford, UK.

Caseres C.H. (1999). The Effect of Mg on the Microstructure and Mechanical Behavior of AlSi-Mg Casting Alloys. Metallurgical and Materials Transactions A. pp. 2611-2618. ISSN-1073-5623.

Castrejón-Valdez, J. D. (1995). Estudio de la Remoción de Antimonio de Aluminio Líquido Mediante la Inyección de Polvos de Calcio-Silicio. Master's Thesis, CINVESTAV Saltillo, México.

DiRusso, E. (1960). Reduction of the Calcium Content of Eutectic Aluminium-Silicon Alloys by Means of Controlled Addition of Phosphorous. Alluminio, Vol. 29, No.3. pp 121127.

Escobedo, J.C., Hernández, J.F., Escobedo, S., Flores, A., and Cortés, D.A. (2003). Estudio cinético de la eliminación de magnesio en las aleaciones de aluminio mediante la inyección de polvos de sílice. Revista de Metalurgia, Madrid, Vol. 39. pp. 172-182. ISSN-0034-8570.

Fishkis, M. (1991). Interfaces and Fracture Surfaces in Saffil/Al-Mg-Cu Metal-Matrix Composites", Journal of Matererials Science. 26 . pp. 2.651-2.661. ISSN-0022-2461.

Flores A., Sukiennik M., Castillejos A. H., Acosta F. A., Escobedo J. C. (1998). A Kinetic Study on the Nucleation and Growth of $\mathrm{Al}_{8} \mathrm{FeMnSi}_{2}$ Intermetallic Compound for Aluminium Scrap Purification", Intermetallics. Vol. 6. pp. 217-227. ISSN-0966-9795.

Flores, A., Muñiz, R., Torres, J., Macías, E., and Rodríguez, N. (2008). Estudio del mecanismo de reacción durante la refinación de magnesio de aleaciones de aluminio líquidas usando partículas de $\mathrm{SiO}_{2}$. Revista de Metalurgia, Madrid. Vol. 44 (2) Marzo-Abril. pp. 138-150. ISSN-0034-8570.

Garant, M., Laslaz, G., Jacob, S., Meyer, P., Gurerin, P.H., Adam, R. (1992). State of the Art use of Sb-Na and Modified Al-Si Casting Alloys. Transactions of the American Foundrymen's Society (AFS), USA. pp. 821-832. ISSN-0065-8375. 
Gariepy B., and Dube, G. (1984). Treating Aluminium (Alloys) with Chlorine. European Patent, EP181227A.

Ghosh, A., Sarkar, R., Mukherjee, B., and Das, S.K. (2003). Effect of Spinel Content on the Properties of Magnesia-Spinel Composite Refractory. Journal of the European Ceramamic Society. Vol. 1. pp. 1-7. ISSN-0955-2219.

Gröbner, J., Kevorkov, D., Schmid-Fetzer, R. (2002). Thermodynamic modeling of Al-Ce-Mg phase equilibria coupled with key experiments. Intermetallics. Vol. 10. pp. 415-422. ISSN-0966-9795.

Gruzleski, J.E., Closset, B.M. (1990). The Treatment of Liquid Aluminium-Silicon Alloys. American Foundrymen's Society Inc., Des Plaines, Illinois, USA. ISBN-087-4331218.

Hallstedt, B., Liu, Z.K., and Agren, J. (1990). Fiber-Matrix Interactions During Fabrication of $\mathrm{Al}_{2} \mathrm{O}_{3}-\mathrm{Mg}$ Metal Matrix Composites. Materials Science and Engineering A. Vol. 129. pp. 135-145. ISSN-0921-5093.

Hardy, C. (1941). Calcium to Purify Scrap Aluminium. Metals Progress, July. pp. 70-71. ISSN0026-0665.

International Center for Diffraction Data ICDD (2009). 12 Campus Blvd. Newton Square, PA 19073-3273 USA; URL:www.icdd.com.

Kattner, U.R. (1997). The Thermodynamic Modeling of Multicomponent Phase Equilibria. Journal of Minerals, Metalsand Materials. Vol. 49, No. 12. pp. 14-19. ISSN-1047-4838.

Langlais, J. (1991). Strontium Extraction by Aluminothermic Reduction. Canadian Metallurgical Quarterly. Vol. 31, No.2. pp. 127-131. ISSN-0008-4433.

Levenspiel, O. (2002). Ingeniería de las Reacciones Químicas. Editorial Reverté 2a Edición. ISBN-9686-7082-94. España. pp. 406-415.

Lloyd, D.J., Jin, I., and Weatherly, G.C. (1994). Controlling the Interface Reaction in Alumina Reinforced Aluminium Composites. Scripta Metallurgica. Vol. 31. pp. 393396. ISSN-1359-6462.

López-Saucedo F. (2006). Estudio Termodinámico y Cinético de la Reducción de $\mathrm{SrCO}_{3}$ por Al(l) Bajo Condiciones de Vacío. Master Thesis. Cinvestav Unidad Saltillo, México.

Macias-Avila, E., Flores-Valdés, A. (1999). A Kinetic Model for Removal of Magnesium from Molten Aluminium by Submerged $\mathrm{Na}_{2} \mathrm{SiF}_{6}$ Powders Injection. Aluminium Transactions, Vol. 1, No. 1. pp. 79-92. ISSN-1521-0200.

Martínez C. (1998). Estudio de la Inyección de Sílice para la Eliminación de Mg en Aluminio. Master's Thesis. CINVESTAV Saltillo, México.

Mcleod, A.D., and Gabryel, C.M. (1992). Kinetics of the Growth of Spinel, $\mathrm{MgAl}_{2} \mathrm{O}_{4}$, on Alumina Particulate in Aluminium-Alloys Containing Magnesium. Metallurgical and Materials Transactions. Vol. A. 23. pp. 1279-1283. ISSN-1073-5623.

Molins, R., Bartoute, J.D., and Bienbenu, A. (1991). Microstructural and Analytical Characterization of $\mathrm{Al}_{2} \mathrm{O}_{3}-(\mathrm{Al}-\mathrm{Mg})$ Composite Interfaces. Matererials Science and Engineering A. Vol. A135. pp. 111-117. ISSN-0921-5093.

Moore, J.J. (1990). Chemical Metallurgy, 2nd Edition. Butterworths. ISBN-04-0805-3690. UK. pp. 322-323.

Moreno, C. (2005). Estudio de la Remoción de Antimonio del Aluminio Líquido Mediante la Adición de Partículas de Calcio. Master's Thesis. CINVESTAV Saltillo, México. 
Muñiz, R., Flores, A., Torres, J. (2008). A Kinetic Study on Strontium Extraction by Metallothermic Reduction Using Submerged SrO Powders Injection. Materials Letters Vol. 62, Issues 4-5. pp. 637-640. ISSN-0167-577X.

Pai, B.C. and Ray, S. (1976). Fabrication of Aluminium-Alumina (Magnesia) Particulate Composites in Foundries Using Magnesium Additions to Melts. Materials Science and Engineering A. Vol. 24. pp. 31-45. ISSN-0921-5093.

Pfeifer, M., Rigsbee, J.M., and Chawla, K.K. (1990). The Interface Microstructure in Alumina (fp) Fiber Magnesium Alloy Composite. Journal of Materials Science. Vol. 25. pp. 1563-1567. ISSN-0022-2461.

Poirier, D.R. and Geiger, G.H. (1994). Transport Phenomena in Materials Processing. TMS Editors, Warrendale, PA, USA. pp. 535-537. ISBN-0873-3927-28.

Rajagopalan, P.K., Sharma, I.G., and Krishan, T.S. (1999). Production of Al-Zr Master Alloy Starting from $\mathrm{ZrO}_{2}$. Journal of Alloys and Compounds. Vol. 285. pp. 212-215. ISSN0925-8388

Randle, V., and Engler, O. (2000). Introduction to Texture Analysis, Macrotexture, Microtexture and Orientation Mapping. Gordon and Breach Science Publishers. ISBN: 9056992244. Netherlands.

Rosenquist, T. (1987). Fundamentos de Metalurgia Extractiva. LIMUSA. ISBN-9681-8214-40. España. pp. 127-139.

Schwartz, A.J., Kumar, M., and Adams, B.L. (2009). Electron Backscatter Diffraction in Materials Science. Kluwer Academic/Plenum Publishers. ISBN: 978-0-387-88135-5. USA.

Tuttle, B.L., Twarog, D., Daniels, E. (1991). The Effect of Trace Amounts of Antimony on Structure and Properties of Aluminium Alloys A356.2. Transactions of the American Foundrymen`s Society, USA. pp. 7-16. ISSN-0065-8375.

Szekely, J., Carlson, J.G., and Helle, L. (1971). Rate Phenomena in Process Metallurgy. Jhon Wiley and Sons, Inc., USA. pp. 369-371. ISBN-0471-8430-32.

Wang, W., Gruzleski, J.E. (1990). Interactive Effects During Sodium or Strontium Treatment of Antimony-Containing A356 Alloy. Transactions of the American Foundrymen`s Society. pp. 227-234.

Wang, W, Gruzleski, J.E. ( 1992). Modifier-Antimony- Interactions - The Problem, Mechanisms and Solution. Proceedings of $3^{\text {rd }}$ international Conference on Molten Aluminium Processing. November 9-10, 1992. Sheraton World Resort, Orlando Florida. pp. 93-124.

Zhong, W.M., Esperance, G.L., and Suery, M. (1995). Interfacial Reactions in Al-Mg (5083)/SICP Composites During Fabrication and Remelting. Metallurgical and Materials Transactions. Vol. A26. pp. 2625-2635. ISSN-1073-5623.

Zhong, W.M., Esperance, G.L., and Suery, M. (2003). Effect of Current Mg Concentration on Interfacial Reactions During Remelting of Al-Mg(5083)/ $\mathrm{Al}_{2} \mathrm{O}_{3}(\mathrm{p})$ Composites", Materials Characterization. Vol. 49. pp. 113-119. ISSN-1044-5803. 


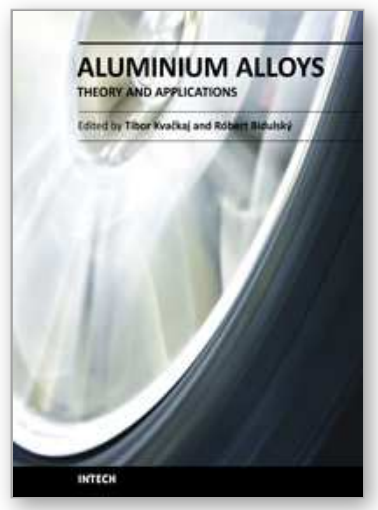

\author{
Aluminium Alloys, Theory and Applications \\ Edited by Prof. Tibor Kvackaj
}

ISBN 978-953-307-244-9

Hard cover, 400 pages

Publisher InTech

Published online 04, February, 2011

Published in print edition February, 2011

The present book enhances in detail the scope and objective of various developmental activities of the aluminium alloys. A lot of research on aluminium alloys has been performed. Currently, the research efforts are connected to the relatively new methods and processes. We hope that people new to the aluminium alloys investigation will find this book to be of assistance for the industry and university fields enabling them to keep up-to-date with the latest developments in aluminium alloys research.

\title{
How to reference
}

In order to correctly reference this scholarly work, feel free to copy and paste the following:

Alfredo Flores and Jesús Torres (2011). New Approaches to Reaction Kinetics during Molten Aluminum Refining Using Electron Backscatter Diffraction (EBSD), Aluminium Alloys, Theory and Applications, Prof. Tibor Kvackaj (Ed.), ISBN: 978-953-307-244-9, InTech, Available from:

http://www.intechopen.com/books/aluminium-alloys-theory-and-applications/new-approaches-to-reactionkinetics-during-molten-aluminum-refining-using-electron-backscatter-diffr

\section{INTECH}

open science | open minds

\section{InTech Europe}

University Campus STeP Ri

Slavka Krautzeka 83/A

51000 Rijeka, Croatia

Phone: +385 (51) 770447

Fax: +385 (51) 686166

www.intechopen.com

\section{InTech China}

Unit 405, Office Block, Hotel Equatorial Shanghai

No.65, Yan An Road (West), Shanghai, 200040, China

中国上海市延安西路65号上海国际贵都大饭店办公楼405单元

Phone: +86-21-62489820

Fax: +86-21-62489821 
(C) 2011 The Author(s). Licensee IntechOpen. This chapter is distributed under the terms of the Creative Commons Attribution-NonCommercialShareAlike-3.0 License, which permits use, distribution and reproduction for non-commercial purposes, provided the original is properly cited and derivative works building on this content are distributed under the same license. 